\title{
The Nutrient Intake and Utilization of Tree Leaves and Green Forage on Growing Kids
}

\author{
Vivekin Pachauri* \\ Jawaharlal Nehru Krishi Vishwa Vidyalaya, Krishi Vigyan Kendra Sagar (M.P), India \\ *Corresponding author
}

\begin{tabular}{l} 
Ke y w or d s \\
Kids, Tree leaves, \\
Fodder \\
\hline Article Info \\
$\begin{array}{l}\text { Accepted: } \\
\text { 28 February } 2018 \\
\text { Available Online: } \\
10 \text { March } 2018\end{array}$ \\
\hline
\end{tabular}

A B S T R A C T
An experiment was conducted with fifteen healthy goat kids of 4-6 month of age and divided into three groups. Experimental feeding was done for 90 days during which a metabolic trial was conducted. At the end of 45 days feeding of tree leaves Albezia lebbek, Ficus glomerata and Sorghums sudananse. The DM digestibility was 55.15 \pm 0.949 , 54.188 \pm 0.980 , 59.34 \pm 0.735 ; Crude Protein was $69.47 \pm 1.10,68.67 \pm 0.42,69.63 \pm 0.84$ and Crude Fiber was $35.19 \pm 0.83,32.44 \pm 1.31,55.91 \pm 1.84$ respectively for group I, II and III. The feed conversion efficiencies were, 3.2, 2.6 and 4.6 $\mathrm{kg}$ per $\mathrm{kg}$ weight gain in for group I, II and III. Mean daily gain in body weight of animals in group I, II and III was $21.78 \pm 0.44,21.78 \pm 0.44$ and $25.78 \pm 0.54$ gram/day respectively showing significant difference among the three groups.

\section{Introduction}

Indian economy has always been influenced by agriculture and animal husbandry and continues to play a major role even in the new millennium. The demand for animal food (milk and meat) has been incessantly increasing for achieving the nutritional satisfaction. The success of livestock farming is greatly dependent on the continuous assured supply of good quality balanced feeds at competitive price. To bridge the gap of demand and supply of feed resources, nonconventional feeds and tree leaves are being widely used to meet the requirements of small ruminants. In corporation of fodder tree shrubs, having multi facet utility on the grazing land substantially adds to availability of feed resources during lean season besides helping in eco-conservation.

The tree leaves are best utilized in browsing by the goat. Information on nutritional characteristic of different varieties of herbs, shrubs, and tree leaves for different locations is scanty. The present study has been carried out to find out the potential feeding value of the tree leaves and to compare them with the sudan grass by feeding the growing kids with the following objectives- 
To study the nutrient utilization of tree leaves in sudan grass by kids.

To study the rate of growth pattern by feeding tree leaves and forage to the kids.

\section{Materials and Methods}

For the present study fifteen healthy kids of about 4-6 months of age with a body weight ranging from $10-15 \mathrm{~kg}$ were selected. The kids of I and II were fed with adlib Serias Albizia lebbek and Dumer Ficus glomerata tree leaves respectively whereas the kids of group III were fed with sudan grass Sorghum sudananse. The feeding of kids was continued for a period of 90 days. At the end of 45 days feeding a metabolic trial was conducted for 6 days on all the kids to study the intake, utilization of nutrients and balance of nitrogen, calcium and phosphorus. The representative samples of the feed offered and the residue left during the metabolism trial were collected for six days for the determination of dry matter intake, proximate principles as per the methods of AOAC. The kids were weighed at weekly interval, average of three days weight was considered for calculating daily gain.

\section{Results and Discussion}

The mean dry matter intake (gram) during experimental feeding was $489.28 \pm 72.86$, $401.96 \pm 47.88$ and $827.55 \pm 72.38$ in group I, II and III respectively which was found to be highly significant difference among the three groups. The organic matter intake was 455.66 $\pm 68.17, \quad 325.50 \quad \pm 39.14, \quad 757.84 \quad \pm 66.36$ gram/day in group I, II and III respectively have significant difference among the three groups. The mean intake of ether extract in group I, II and III was $30.74 \pm 4.52,16.50$ $\pm 1.96,17.63 \pm 1.55 \mathrm{gram} /$ day respectively. The data revealed that there was a highly significant difference in the mean intake of ether extract. The mean intake of total carbohydrates was $339.27 \pm 51.12,254.56$ $\pm 30.79,674.39 \pm 58.77$ gram/day in group I, II and III respectively and the difference was found to be highly significant among the three groups. The intake of crude fibre in group I, II and III was $131.85 \pm 20.96,45.32 \pm 5.85$, $264.918 \pm 23.20$ gram/day respectively and there was highly significant difference among the three groups (Table 1). Similarly the mean NFE intake was $207.41 \pm 30.15,206.17$ $\pm 25.01,405.37 \pm 52.44$ gram/day in group I, II and III respectively which was observed to be a highly significant difference among groups $(\mathrm{P}<0.01)$. The average body weight of kids at the beginning and at the end of experiment as well as the total body weight gain along with weekly and daily gain of the experimental animal has been presented in table 2 .

Total weekly weight mean of gain in body weight in the three groups (Serias) Albizia lebbek (group I), Dumer Ficus glomerata (Group II and sudan grass Sorghum sudananse (group III) was found to be 152.52 $\pm 3.12, \quad 152.52 \quad \pm 3.12$ and $180.54 \quad \pm 3.82$ gram/week respectively showing significant difference between the groups I, II and III. Mean daily gain in body weight of animals in group I, II and III was $21.78 \pm 0.44,21.78$ \pm 0.44 and $25.78 \pm 0.54$ gram/day respectively showing significant difference among the three groups.

The mean dry matter intake during the present experimental feeding of Albizia lebbek leaves was $489.28 \pm 72.86$ gram/day. Albizia lebbek leaves was fed in three different proportion in goats viz., 85:15 T1, 70:30 T2 and 55:45 T3 with dry grass Sehima heteropogon and reported the dry matter intake gram/day T1 $426.83 \pm 30.24, \mathrm{~T} 2 \quad 443.79 \pm 38.7$ and $\mathrm{T} 3$ $426.10 \pm 9.81$ for the three treatments and concluded that the supplementation of Albizia lebbek leaves dispersed the intake of mature dry grass in goats. 
Table.1 Average nutrient intake gram/day of experimental animals

\begin{tabular}{|l|c|c|c|}
\multicolumn{1}{|c|}{ Attributes } & Group I & Group II & Group III \\
\hline Dry matter intake & $489.288 \pm 72.86$ & $401.96 \pm 47.88$ & $827.55 \pm 72.38$ \\
\hline Organic matter intake & $455.66 \pm 68.17$ & $325.50 \pm 39.14$ & $757.84 \pm 66.36$ \\
\hline Crude protein intake & $85.77 \pm 12.57$ & $54.48 \pm 6.43$ & $66.04 \pm 6.07$ \\
\hline Ether extract intake & $30.74 \pm 4.52$ & $16.50 \pm 1.96$ & $17.63 \pm 1.55$ \\
\hline Crude fibre intake & $131.85 \pm 20.96$ & $45.32 \pm 5.85$ & $264.91 \pm 23.20$ \\
\hline Nitrogen free extract intake & $207.41 \pm 30.15$ & $206.17 \pm 25.01$ & $405.37 \pm 52.44$ \\
\hline Total carbohydrate intake & $339.27 \pm 51.12$ & $254.56 \pm 30.79$ & $674.39 \pm 58.77$ \\
\hline
\end{tabular}

Table.2 Weekly and daily body weight gain, feed gain ratio of experimented kids (Mean \pm SE)

\begin{tabular}{|l|l|l|l|l|l|} 
Groups & $\begin{array}{l}\text { Initial } \\
\text { body } \\
\text { Weight }\end{array}$ & $\begin{array}{l}\text { Final } \\
\text { body } \\
\text { Weight }\end{array}$ & $\begin{array}{l}\text { Weight } \\
\text { gain }(\mathbf{g m} .)\end{array}$ & $\begin{array}{l}\text { Weekly gain } \\
(\text { gm.) }\end{array}$ & $\begin{array}{l}\text { Daily gain } \\
(\text { gm.) }\end{array}$ \\
\hline I & 12.200 & 14.16 & 1.96 & $152.52 \pm 3.12$ & $\mathbf{2 1 . 7 8 \pm 0 . 4 4}$ \\
\hline II & 11.72 & 13.96 & 1.96 & $152.52 \pm 3.12$ & $\mathbf{2 1 . 7 8 \pm 0 . 4 4}$ \\
\hline III & $\mathbf{1 1 . 8 8 0}$ & $\mathbf{1 4 . 0 0}$ & $\mathbf{2 . 3 2}$ & $\mathbf{1 8 0 . 5 4} \pm \mathbf{3 . 8 2}$ & $\mathbf{2 5 . 7 8 \pm 0 . 5 4}$ \\
\hline
\end{tabular}

The mean dry matter intake of Ficus glomerata tree leaves was $401.96 \pm 47.88$ as reported by others (Balaram and Gupta, 1990). Dry matter intake of Ficus nemoralis (Dudhilo) was $1.6 \pm 0.06 \mathrm{~kg} /$ day in calves, which is quite low. They opined that high tanic acid content in Dudhilo leaves might be responsible for reduced palatability reported by other workers (Jain, 1998). The mean dry matter intake of sudan grass (gram/day) Sorghum sudananse under experimental feeding was $827.55 \pm 72.38$.

The findings were in close agreement with the other workers (Singh et al., 1998). The dry matter intake of goats fed with (Sola grass) Aexhynoner indica is gram/day 1021.67 \pm 61.83 . The higher dry matter intake was probably due to the selective feeding habit of goats especially due to the selective feeding habit of goats especially for the tenderous apical parts of the plant. It can be concluded that goats can be reared on (Sola grass) without any deleterious effect on their health. The findings were in close agreement with the other workers (Singh et al., 1998).

\section{Daily body weight gain}

The result in the present study of mean daily gain in body weight of animals in group I, II, and III was $21.78 \pm 0.44,21.78 \pm 0.44,21$ and $25.75 \pm 0.54$ respectively showing significant difference among three groups. The result in the present study are in agreement with the observation made by workers (Singh et al., 1998), reported $25 \pm 6.45$ change in body weight gain/day of goats fed on (Sola grass) Aexhynoner indica which might be due to higher digestibility of nutrients. The nutritional evaluation of Guinea grass Penicum maximum in goats reported lower DM, CP, EE, Ash 35.42\%, 3.65\%, 1.50\%, $7.49 \%$ and higher $\mathrm{CF}$ and TCHO $39.13 \%$, $87.36 \%$ respectively while $\mathrm{OM}$ values were comparable $92.51 \%$ against the corresponding reported values $64.1 \%, 8.24 \%, 2.14 \%, 8.36 \%$, $32.04 \%, 81.26 \%, 91.64 \%$ by others (Singh et al., 1987). The daily voluntary DM intake of mixed Jungle grass was fed to the goats was 52.68 gram $/ \mathrm{kg} \mathrm{W}^{0.75}$. The mixed Jungle grass met the maintenance requirement of goats in terms of DCP, calcium and phosphorus but 
could not provide enough DM and TDN, thus requiring supplementation with energy rich feeds as reported by many workers (Tiwari et al., 1996).

\section{References}

Balaram, N and Gupta, H.K. (1990). Nutritive value of mixed Jungle grass for goats in Sikkim. Indian J. Anim Nutr 7 (1)63-66.

Jain, R.K., Tiwari, S.P., Chourasia, S.K. and Rajagopl, S. (1998), Nutritional evaluation of (Sola grass) Aexhynoner indica in goats. Indian J. Anim Nutr, 15 (1)35-39.
Singh, A.K., Upadhyay, V.S. Singh, K.K. and Mishra, A.K. (1998) effect of dietary leaves of Albizia lebbek, on the utilization of mature dry leaves in goats. Indian J.Anim, Nutr., 15 (4):129-133.

Singh, R.B. Banerjee, G.C. and Gupta, B.N. (1987) Chemical composition and nutritive value of Ficus nemoralis (Dudhilo) tree leaves. Indian J. Anim, Nutr., 4(3): 212-213.

Tiwari, D.P., Jain, R.K., Maiti, S.K., Nema, R.K., Barik, A.K. (1996). Nutritional evaluation of Guinea grass in goats. Indian J. Anim, Nutr., 13(4) :240.

\section{How to cite this article:}

Vivekin Pachauri. 2018. The Nutrient Intake and Utilization of Tree Leaves and Green Forage on Growing Kids. Int.J.Curr.Microbiol.App.Sci. 7(03): 3503-3506.

doi: https://doi.org/10.20546/ijcmas.2018.703.403 